\title{
Experimental and Theoretical Evaluation on the Effect of the Terminal Side Chain of a Polymeric Surfactant on the Inhibition Efficiency of Aluminum Corrosion in Acid Medium
}

\author{
S.M. Sayyah, ${ }^{a, *}$ M.M. El-Deeb, ${ }^{a, b}$ S.S. Abd El-Rehim, ${ }^{c}$ \\ R.A. Ghanem, ${ }^{d}$ S.M. Mohamed ${ }^{a}$ \\ ${ }^{a}$ Polymer Research Lab., Chemistry Department, Faculty of Science, Beni Suef University, \\ 62514 Beni Suef, Egypt \\ ${ }^{b}$ Chemistry Department, Faculty of Science, Ha'il University, P. Box 2440, \\ 81451 Ha'il, Saudia Arabia \\ ${ }^{c}$ Chemistry Department, Faculty of Science, Ain Shams University, Abasia, Egypt. \\ ${ }^{d}$ Department of Chemistry, University of A-al-Bayt,P.O. Box 130040, \\ Mafraq 25113, Jordan
}

Received 15 October 2014; accepted 25 October 2014

\begin{abstract}
Inhibition effect of poly 3-dodecyloxy aniline polymeric surfactant $\left(\mathrm{PC}_{12} \mathrm{H}\right)$ on the corrosion of aluminum in $0.5 \mathrm{M} \mathrm{HCl}$ solution was investigated using potentiodynamic polarization technique under different experimental conditions. Inhibition efficiency and thermodynamic functions for dissolution and adsorption of $\mathrm{PC}_{12} \mathrm{H}$ are compared with Poly 3-(dodecyloxy sulfonic acid) aniline $\left(\mathrm{PC}_{12} \mathrm{SO}_{3} \mathrm{H}\right)$ to explain the effect of terminal side chain on the corrosion protection. Data show that the presence of $-\mathrm{SO}_{3} \mathrm{H}$ as a terminal group in $\mathrm{PC}_{12} \mathrm{SO}_{3} \mathrm{H}$ decreases the inhibition efficiency from $88.7 \%$, in case of $\mathrm{PC}_{12} \mathrm{H}$, to $55.1 \%$ in case of $\mathrm{PC}_{12} \mathrm{SO}_{3} \mathrm{H}$. Quantum chemical calculations were performed on $\mathrm{PC}_{12} \mathrm{H}$ and $\mathrm{PC}_{12} \mathrm{SO}_{3} \mathrm{H}$ to investigate the relationship between the molecular structures and their inhibition efficiencies.
\end{abstract}

Keywords: Corrosion, Polymers, Electrochemical Techniques, Adsorption, Thermodynamic Properties, Computational Techniques.

\section{Introduction}

Corrosion inhibitors play a very important role in protecting metals and alloys. Aluminum has a remarkable economic and industrial importance owing to its low cost, light weight, high thermal and electrical conductivity. The most important feature of aluminum is its corrosion resistance due to the formation of a

\footnotetext{
*Corresponding author. E-mail address: smsayyah@ hotmail.com
} 
protective film on its surface upon its exposure to atmosphere or water [1]. Several authors [2-4] studied the corrosion of aluminum and their inhibition by organic inhibitors in acid solutions. Various surfactants as 1, 1-(laurly amido) propyl ammonium chloride are being studied as a corrosion inhibitor for pure aluminum in acid media [5-6]. Many of organic compounds as electroactiveconducting polymers [7-10], carboxylic organic acids [11, 12], fatty acids [13], dicyandiamide and some of its related compounds [14], hydrazine compounds [15], triazole and thiazole derivatives [16], were also found to inhibit the corrosion of aluminum.

Sayyah et al. $[17,18]$ studied the inhibition effect of the series of the prepared monomeric surfactants and their analog polymers with different hydrophilic side chain length on the corrosion of aluminum in acid medium. Results indicate that the hydrophilic side chain has remarkable influence on the inhibition efficiency of the prepared surfactants and the inhibition efficiency increases in both monomeric and polymeric surfactants as the length of the side chain increases.

Effect of 3-(10-sodiumsulfonate decyloxy) aniline monomeric surfactant and its analog polymer on the corrosion of aluminum in $0.5 \mathrm{M} \mathrm{HCl}$ was studied [19]. The results indicate that the inhibition occurs through the adsorption of surfactant molecules on the aluminum surface as well as the inhibition efficiency increases with increasing the inhibitor concentrations, and decreases with raising the temperature.

Quantum chemistry calculations have been widely used to evaluate the inhibition performance of corrosion inhibitors, which can quantitatively study the relationship between inhibition efficiency and molecular reactivity [20-22]. With this method, the capability of inhibitor molecules to donate or accept electrons can be predicted with analysis of the global reactivity parameters, such as energy gap between HOMO and LUMO, chemical potential, hardness, softness, dipole moment, and electrophilicity index, etc.

Zhang et al. [23] studied the corrosion inhibition of four 1-R-2-undecylimidazoline compounds for carbon steel by quantum chemistry and molecular mechanics methods. Results indicate that the hydrophilic groups (R) affect on the molecular reactivity, binding strength between self-assembled monolayer and Fe surface, and compactness of the inhibitor.

The present study aims to investigate the inhibition effect of poly 3-dodecyloxy aniline polymeric surfactant $\left(\mathrm{PC}_{12} \mathrm{H}\right)$ on the corrosion of aluminum in $0.5 \mathrm{M} \mathrm{HCl}$ solution using potentiodynamic polarization techniques, as well as the inhibition efficiency and thermodynamic functions for dissolution and adsorption of $\mathrm{PC}_{12} \mathrm{H}$ are compared with our previous data for $\mathrm{PC}_{12} \mathrm{SO}_{3} \mathrm{H}$ to explain the effect of the terminal side chain on the corrosion protection of these two compounds. Quantum chemical calculations were performed on $\mathrm{PC}_{12} \mathrm{H}$ and $\mathrm{PC}_{12} \mathrm{SO}_{3} \mathrm{H}$ to determine the relationship between the molecular structures and their inhibition efficiencies. 


\section{Experimental}

\section{Materials}

Poly 3-dodecyloxy aniline $\left(\mathrm{PC}_{12} \mathrm{H}\right)$ and poly 3-(dodecyloxy sulfonic acid) aniline $\left(\mathrm{PC}_{12} \mathrm{SO}_{3} \mathrm{H}\right)$ have been prepared by Sayyah et al. $[18,24]$ and the structures are given in scheme (1).

Concentrated hydrochloric acid is chemically a pure grade product provided by Prolabo-Chemical Co., (U.K.). Bi-distilled water is used to prepare all solutions.

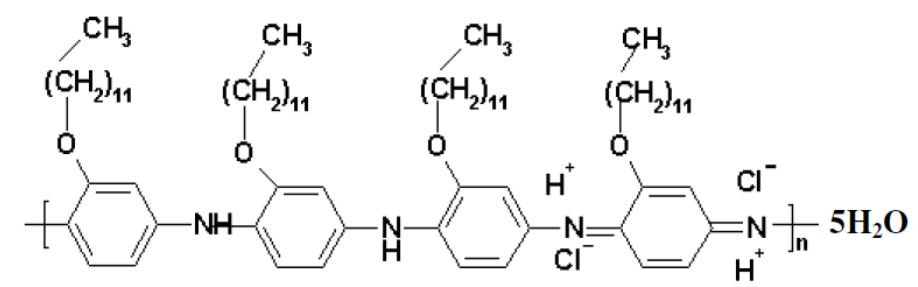

Poly 3-dodecyloxy aniline $\left(\mathrm{PC}_{12} \mathrm{H}\right)$

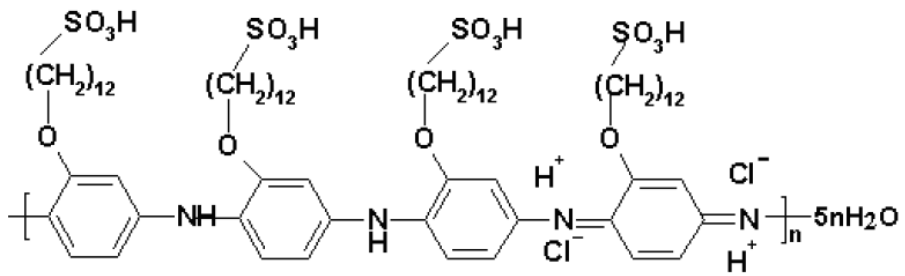

Poly 3-(dodecyloxy sulfonic acid) aniline $\left(\mathrm{PC}_{12} \mathrm{SO}_{3} \mathrm{H}\right)$

Scheme 1. Structures of the prepared $\left(\mathrm{PC}_{12} \mathrm{H}\right)$ and $\left(\mathrm{PC}_{12} \mathrm{SO}_{3} \mathrm{H}\right)$.

\section{Potentiodynamic polarization measurements}

Working electrode is made of aluminum metal provided by the Egyptian Aluminum Company, Naga Hammadi, Egypt, which has the following chemical composition (wt $\%$ ): $99.57 \% \mathrm{Al}, 0.31 \% \mathrm{Fe}, 0.07 \% \mathrm{Si}, 0.015 \% \mathrm{Ti}, 0.0016 \% \mathrm{Zn}$, $0.0003 \% \mathrm{Cr}, 0.0019 \% \mathrm{Mg}, 0.0021 \% \mathrm{Mn}$ and $0.0007 \% \mathrm{Cu}$.

The rod is axially embedded in Araldite holder to offer an active flat disc shaped of surface area $0.785 \mathrm{~cm}^{2}$. Prior to each experiment, the working electrode was polished successively with fine emery paper. The polished metal surface was rinsed with acetone and distilled water before dipping it into the electrolytic cell. A platinum wire was used as the counter electrode and a saturated calomel electrode as a reference electrode to which all potentials are referred.

Electrochemical experiments were performed using a Wenking PGS95, Potentiostat /Galvanostat connected to a PC computer. Current potential curves $(I-E)$ are recorded with a computer software (ECT). Experiments were carried out by changing the electrode potential automatically from the starting potential towards more positive values using scan rate of $25 \mathrm{mVs}^{-1}$ till the end of the experiments.

\section{Computational techniques}

Quantum chemical calculations were conducted with hyperchem 8.0 and Chem Bio3D Ultra software. The 3D structure of the inhibitor molecules was constructed with the build module implemented in HyperChem 8.0 software 
package and subsequently, optimized using molecular mechanics calculations, $\mathrm{MM}+$ force field implemented in both software packages. The MM+ force field is an extension of MM2; force field refers to both an interatomic potential functional form and its relative parameters. Interatomic potentials are mathematical functions used to describe the potential energy of a statistical mechanical model formed by a system of particles. MM2 was developed primarily for conformational analysis of hydrocarbons and other small organic molecules. Calculations of the inhibitor molecules were accomplished by MM+. Frontier orbital's distribution, energy of optimized structure, bond length and bond angle were also obtained. On the other hand, analysis of the electrostatic potential surfaces (ESP) of the two compounds was made using the semiempirical ZINDO method using Argus Lab 4 software.

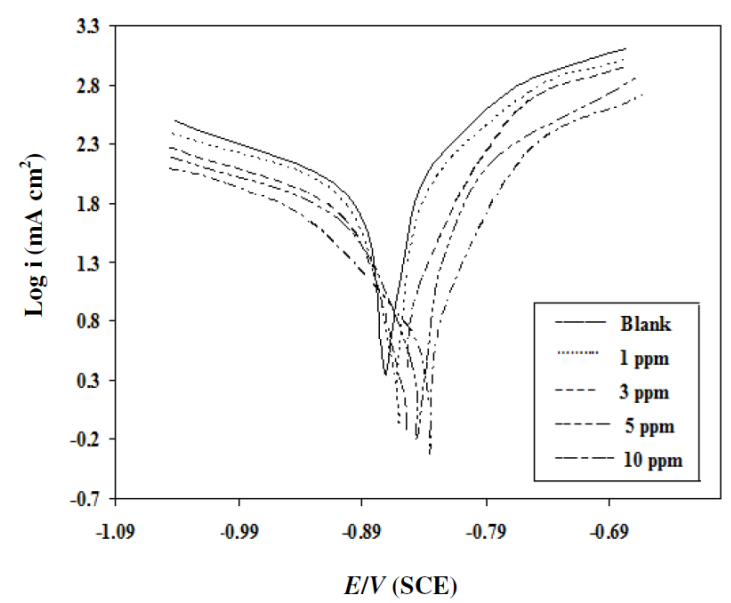

Figure 1. Effect of $\mathrm{PC}_{12} \mathrm{H}$ concentrations on the anodic and cathodic polarization of aluminum in $0.5 \mathrm{M} \mathrm{HCl}$ with a scan rate of $25 \mathrm{mVs}^{-1}$ at $30^{\circ} \mathrm{C}$.

\section{Results and discussion}

\section{Potentiodynamic polarization measurement}

Fig. 1 shows Tafel polarization curves of aluminum in $0.5 \mathrm{M} \mathrm{HCl}$ solution in the absence and presence of different concentrations of $\mathrm{PC}_{12} \mathrm{H}$ at $30{ }^{\circ} \mathrm{C}$ with a scan rate of $25 \mathrm{mVs}^{-1}$. The electrochemical kinetic parameters, including Tafel constants for both cathodic $\left(\beta_{\mathrm{c}}\right)$ and anodic $\left(\beta_{\mathrm{a}}\right)$ reactions, the corrosion current densities $\left(I_{\text {corr }}\right)$ and the corrosion potentials $\left(E_{\text {corr }}\right)$, were obtained and are listed in Table 1, and are compared with the data that we have obtained in our previous work in case of $\mathrm{PC}_{12} \mathrm{SO}_{3} \mathrm{H}$ [18]. The inhibition efficiency $(P \%)$ was calculated according to Eq. (1) and is depicted in Table 1.

$$
(P \%)=100 \times\left[1-\left(I_{\text {corr }}\right) /\left(I_{\text {corr }}\right)_{\mathrm{o}}\right]
$$

where $\left(I_{\text {corr }}\right)_{0}$ and $\left(I_{\text {corr }}\right)$ are the corrosion current densities in the absence and presence of inhibitor surfactants, respectively. Results indicate that the corrosion current density decreases with an increase in the inhibitor concentrations for both polymeric surfactants and the lowest value of $10.68 \mu \mathrm{A} \mathrm{cm} \mathrm{cm}^{-2}(P \%=88.7)$ is obtained with $\mathrm{PC}_{12} \mathrm{H}$, indicating that $\mathrm{PC}_{12} \mathrm{H}$ is more effective corrosion inhibitor than $\mathrm{PC}_{12} \mathrm{SO}_{3} \mathrm{H}$. 
Table 1. Electrochemical kinetic parameters and inhibition efficiency of aluminum in $0.5 \mathrm{M} \mathrm{HCl}$ solution at different temperatures.

\begin{tabular}{|c|c|c|c|c|c|c|c|c|c|c|}
\hline \multicolumn{11}{|c|}{$30^{\circ} \mathrm{C}$} \\
\hline \multirow{2}{*}{$\begin{array}{c}C, \\
\text { ppm }\end{array}$} & \multicolumn{2}{|c|}{$\begin{array}{c}-E_{\text {Corr }} \\
\text { (V vs. SCE) }\end{array}$} & \multicolumn{2}{|c|}{$\begin{array}{c}I_{\text {Corr }} \\
\left(\mu \mathrm{A} \mathrm{\mathbf {cm } ^ { - 2 }}\right)\end{array}$} & \multicolumn{2}{|c|}{$\begin{array}{c}\boldsymbol{\beta}_{\mathrm{a}} \\
\left(\mathbf{m V V} \operatorname{dec}^{-1}\right)\end{array}$} & \multicolumn{2}{|c|}{$\begin{array}{c}\boldsymbol{\beta}_{\mathrm{c}} \\
\left(\mathbf{m V} \mathbf{d e c}^{-1}\right)\end{array}$} & \multicolumn{2}{|r|}{$P \%$} \\
\hline & $\mathrm{PC}_{12} \mathrm{H}$ & $\mathrm{PC}_{12} \mathrm{SO}_{3} \mathrm{H}^{[18]}$ & $\mathrm{PC}_{12} \mathrm{H}$ & $\mathrm{PC}_{12} \mathrm{SO}_{3} \mathrm{H}^{[18]}$ & $\mathrm{PC}_{12} \mathrm{H}$ & $\mathrm{PC}_{12} \mathrm{SO}_{3} \mathrm{H}^{[18]}$ & $\mathrm{PC}_{12} \mathrm{H}$ & $\mathrm{PC}_{12} \mathrm{SO}_{3} \mathrm{H}^{[18]}$ & $\mathrm{PC}_{12} \mathrm{H}$ & $\mathrm{PC}_{12} \mathrm{SO}_{3} \mathrm{H}^{[18]}$ \\
\hline $\mathbf{0}$ & 0.82 & 0.82 & 95.22 & 95.22 & -0.34 & -0.34 & 0.04 & 0.04 & - & - \\
\hline 1 & 1.05 & 1.04 & 37.80 & 60.80 & -0.17 & -0.26 & 0.61 & 0.33 & 60.3 & 36.2 \\
\hline 3 & 0.66 & 0.60 & 22.03 & 46.73 & -0.39 & -0.36 & 0.29 & 0.26 & 76.6 & 50.12 \\
\hline 5 & 0.86 & 0.74 & 18.02 & 29.79 & -0.27 & -0.29 & 0.17 & 0.08 & 81.1 & 69.82 \\
\hline 10 & 0.85 & 0.70 & 10.68 & 42.82 & -0.33 & -0.32 & 0.14 & 0.13 & 88.7 & 55.10 \\
\hline \multicolumn{11}{|c|}{$40^{\circ} \mathrm{C}$} \\
\hline 0 & 0.98 & 0.98 & 368.0 & 368.00 & -0.39 & -0.39 & 0.12 & 0.12 & - & - \\
\hline 1 & 0.98 & 0.94 & 202.7 & 256.70 & -0.34 & -0.32 & 0.12 & 0.11 & 44.9 & 30.2 \\
\hline 3 & 0.95 & 0.84 & 163.2 & 216.20 & -0.33 & -0.39 & 0.30 & 0.11 & 55.7 & 41.2 \\
\hline 5 & 0.94 & 0.89 & 144.3 & 186.30 & -0.37 & -0.34 & 0.12 & 0.15 & 60.8 & 49.4 \\
\hline 10 & 0.97 & 0.93 & 122.6 & 193.10 & -0.41 & -0.43 & 0.12 & 0.09 & 66.7 & 47.5 \\
\hline \multicolumn{11}{|c|}{$50^{\circ} \mathrm{C}$} \\
\hline $\mathbf{0}$ & 1.03 & 1.03 & 574.2 & 574.20 & -0.46 & -0.46 & 0.13 & 0.13 & - & - \\
\hline 1 & 0.98 & 0.95 & 409.1 & 440.50 & -0.31 & -0.45 & 0.13 & 0.11 & 28.8 & 23.3 \\
\hline 3 & 0.91 & 0.97 & 365.3 & 401.10 & -0.45 & -0.41 & 0.12 & 0.11 & 36.4 & 29.9 \\
\hline 5 & 0.82 & 0.98 & 338.6 & 366.50 & -0.52 & -0.35 & 0.20 & 0.15 & 41.1 & 36.2 \\
\hline 10 & 0.81 & 0.90 & 310.3 & 383.40 & -0.10 & -0.43 & 0.18 & 0.09 & 45.9 & 33.2 \\
\hline \multicolumn{11}{|c|}{$60^{\circ} \mathrm{C}$} \\
\hline $\mathbf{0}$ & 1.21 & 1.21 & 783.0 & 783.00 & -0.48 & -0.48 & 0.13 & 0.13 & - & - \\
\hline 1 & 1.16 & 0.95 & 631.3 & 632.30 & -0.43 & -0.55 & 0.12 & 0.12 & 19.4 & 19.2 \\
\hline 3 & 0.96 & 0.97 & 603.9 & 602.50 & -0.42 & -0.43 & 0.14 & 0.14 & 22.9 & 23.1 \\
\hline 5 & 0.94 & 0.98 & 533.5 & 578.60 & -0.47 & -0.46 & 0.11 & 0.14 & 31.9 & 26.1 \\
\hline 10 & 1.02 & 0.90 & 524.4 & 603.20 & -0.41 & -0.56 & 0.11 & 0.10 & 33.1 & 23.0 \\
\hline
\end{tabular}

In acidic solutions, the anodic process of corrosion is the passage of metal ions from the metal surface into the solution, while the principle of cathodic process is the discharge of hydrogen ions to produce hydrogen gas, and the inhibitor may affect either one or both of the anodic and cathodic processes [25]. When the change in the $E_{\text {corr }}$ value is greater than $85 \mathrm{mV}$, a compound can be recognized as an anodic or cathodic type inhibitor [26].

Inspections of these data reveal that the presence of $\mathrm{PC}_{12} \mathrm{H}$ and $\mathrm{PC}_{12} \mathrm{SO}_{3} \mathrm{H}$ shifts the corrosion potential $\left(E_{\text {corr }}\right)$ towards less negative values, indicating that the studied polymeric surfactants act predominantly as an anodic type inhibitor, and thus, the polymeric surfactant inhibitors are probably adsorbed on the anodic part of the aluminum surface and form a barrier layer of adsorbed molecules that separates the metal from direct contact with the corrosion medium. The adsorption behavior is attributed to the presence of electrostatic interaction between the adsorption centers of the surfactant polymer inhibitors and the metal surface.

It is found that the maximum inhibition efficiency of $\mathrm{PC}_{12} \mathrm{H}(P \%=88.7)$ is higher than that of $\mathrm{PC}_{12} \mathrm{SO}_{3} \mathrm{H}(\mathrm{P} \%=55.1)$, Although, the two compounds have the same number of carbon atoms in the alkyl chain but the difference in the protection can be attributed to the terminal group; the presence of $\mathrm{CH}_{3}$ as a terminal group in $\mathrm{PC}_{12} \mathrm{H}$ decreases the repulsion between the inhibitor and the negatively charged aluminum surface and allows a closed layer from the inhibitor to be adsorbed 
more easily on aluminum surface and hence increasing the inhibition efficiency. These results are in a good agreement with the results obtained from the theoretical calculations.

The effect of temperature on the corrosion of aluminum in $0.5 \mathrm{M} \mathrm{HCl}$ solution in the absence and presence of $10 \mathrm{ppm}$ of $\mathrm{PC}_{12} \mathrm{H}$ and $\mathrm{PC}_{12} \mathrm{SO}_{3} \mathrm{H}$ [18] with scan rate of $25 \mathrm{mVs}^{-1}$ was studied and the electrochemical kinetic parameters are tabulated in Table (1). It is observed that the corrosion current densities $\left(I_{\text {corr }}\right)$ in the absence and presence of both inhibitors increase with increasing the temperature. Such results declared that the rate of corrosion of aluminum enhanced with increasing the temperature. The inhibition efficiency $(P \%)$ of both $\mathrm{PC}_{12} \mathrm{H}$ and $\mathrm{PC}_{12} \mathrm{SO}_{3} \mathrm{H}$ was calculated at different temperatures and is given in Table 1.

It has been reported [17 - 19] that, for acid corrosion of metals, the logarithm of the corrosion rate is a linear function with 1/T (following Arrhenius equation type)

$$
\log C R(\text { Corrosion rate })=-E_{\mathrm{a}} / 2.303 R T+A
$$

where $E_{\mathrm{a}}$ is the apparent activation energy, $R$ is the universal gas constant and $A$ is the Arrhenius pre-exponential factor. The logarithm of the corrosion rate was plotted against $1 / T$ (c.f. Fig. 2) for each concentration and the values of $\left(E_{\mathrm{a}}\right)$ have been calculated and tabulated in Table 2. An alternative formula of the Arrhenius equation is the transition state equation:

$$
\text { Corrosion Rate }=R T / N h \exp \left(\Delta S^{\mathrm{o}} / R\right) \exp \left(-\Delta H^{\mathrm{o}} / R T\right)
$$

where $h$ is the Planck's constant, $N$ is the Avogadro's number, $\Delta S^{0}$ is the entropy of the activation, and $\Delta H^{0}$ is the enthalpy of activation. The plot of log (Corrosion Rate / T) vs. $1 / T$ gives a straight line with a slope of $\left(-\Delta H^{\circ} / 2.303 R\right)$, from which the values of $\Delta H^{\mathrm{o}}$ are calculated and listed in Table 2.

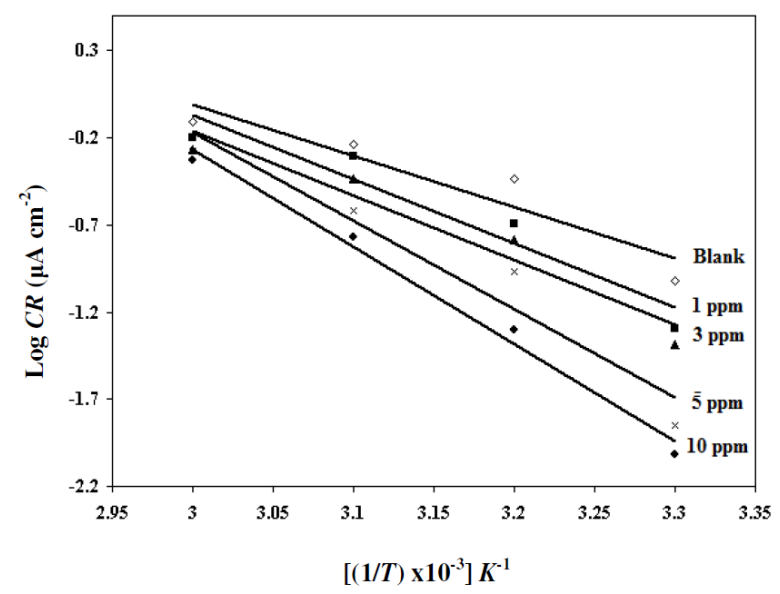

Figure 2. Arrhenius plot of corrosion rate of aluminum in $0.5 \mathrm{M} \mathrm{HCl}$ containing various concentrations of $\mathrm{PC}_{12} \mathrm{H}$. 
Table 2. Effect of $\mathrm{PC}_{12} \mathrm{H}$ concentrations on the thermodynamic of the dissolution process of aluminum in $0.5 \mathrm{M} \mathrm{HCl}$ solution.

\begin{tabular}{|c|c|c|c|}
\hline $\begin{array}{c}C, \\
\text { ppm }\end{array}$ & $\begin{array}{c}E \mathbf{a} \\
\mathrm{kJ}^{\mathrm{mol}} \mathrm{mol}^{-1}\end{array}$ & $\begin{array}{c}\Delta H^{\mathbf{o}} \\
\mathbf{k J} \mathrm{mol}^{-1}\end{array}$ & $\begin{array}{c}\Delta S^{0} \\
\mathrm{~kJ} \mathrm{~mol}^{-1} \mathrm{~K}^{-1}\end{array}$ \\
\hline Blank & 57.30 & 55.4 & 0.381 \\
\hline 1 & 71.61 & 68.97 & 0.267 \\
\hline 3 & 71.99 & 69.36 & 0.268 \\
\hline 5 & 99.37 & 96.88 & 0.039 \\
\hline 10 & 109.31 & 106.65 & 0.016 \\
\hline
\end{tabular}

It is obvious that the value of $E_{\mathrm{a}}$ is higher in the presence of both $\mathrm{PC}_{12} \mathrm{H}$ and $\mathrm{PC}_{12} \mathrm{SO}_{3} \mathrm{H}$ when compared with the blank and the value in case of $\mathrm{PC}_{12} \mathrm{H}(10$ $\mathrm{ppm}$ ) is $109.31 \mathrm{~kJ} \mathrm{~mol}^{-1}$, while it is $76.2 \mathrm{~kJ} \mathrm{~mol}^{-1}$ [18] in the case of $\mathrm{PC}_{12} \mathrm{SO}_{3} \mathrm{H}$ $(10 \mathrm{ppm})$, which agrees with our results indicating that $\mathrm{PC}_{12} \mathrm{H}$ is more effective corrosion inhibitor than $\mathrm{PC}_{12} \mathrm{SO}_{3} \mathrm{H}$. Furthermore, with increasing the concentrations of both the polymeric surfactant inhibitors, the activation energies increase and the inhibition efficiency decreases; this behavior is attributed to an appreciable decrease in the adsorption process of the inhibitors on the metal surface with increasing the temperature [27,28]. A decrease in inhibition efficiencies $(P \%)$ with increasing the temperature, with analogous increase in corrosion activation energy $\left(E_{\mathrm{a}}\right)$ in the presence of the inhibitors compared to their absence is a good evidence of the physical adsorption mechanism [27,29].

$\Delta H^{\mathrm{o}}$ for the corrosion of $\mathrm{Al}$ in the presence of $\mathrm{PC}_{12} \mathrm{H}$ and $\mathrm{PC}_{12} \mathrm{SO}_{3} \mathrm{H}$ is higher than that of blank solution and increases with an increase in the inhibitors concentrations, indicating that more energy barrier for the corrosion reaction in the presence of the inhibitor is attained and this energy barrier of corrosion reaction increases as the concentration of the inhibitor increases.

\section{Adsorption isotherm}

In order to get more information about the mode of adsorption of the inhibitors on the metal surface at different temperatures, the obtained data have been tested with several adsorption isotherms. Experimental data were fitted into Langmuir adsorption isotherm as shown in Fig. 3. The adsorption isotherm relationship is represented by the following equation $[18,19]$ :

$$
C_{\mathrm{i}} / \theta=1 / K_{\mathrm{ads}}+C_{\mathrm{i}}
$$

Values of $C_{i}$ are the concentration of the inhibitor in bulk solution, $\theta$ is the surface coverage $(\theta=P / 100)$ and $K_{a d s}$ is the adsorption equilibrium constant. 


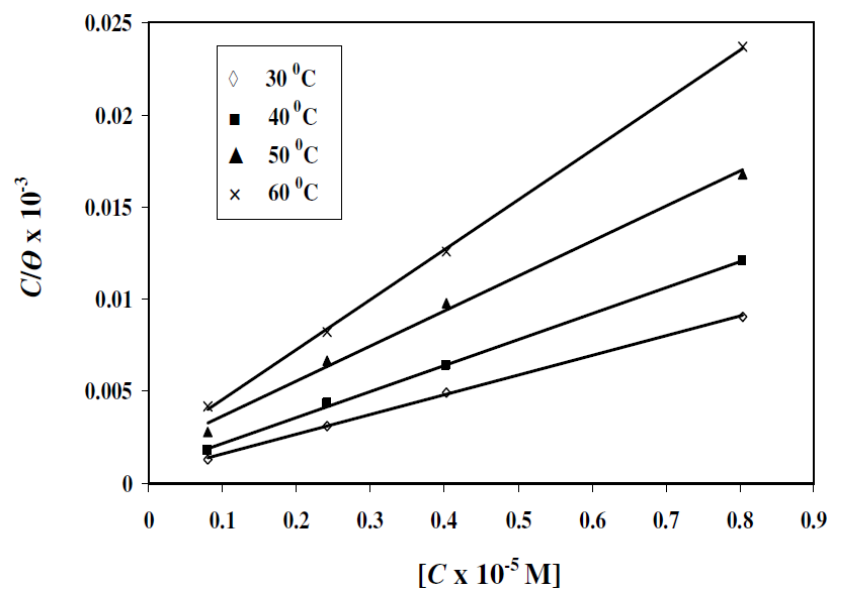

Figure 3. Langmuir adsorption isotherm of $\mathrm{PC}_{12} \mathrm{H}$ at different temperatures.

Frumkin isotherm [18, 19] was also found to fit well with the obtained experimental data, as represented in Fig. 4. The adsorption isotherm relationship of Frumkin is represented by the following equation:

$$
\ln \theta / C_{\mathrm{i}}(1-\theta)=\ln K_{\text {ads }}+2 a \theta
$$

where $(a)$ is the lateral interaction term describing the molecular interactions in the adsorption layer and the heterogeneity of the surface and is a measure for the steepness of the adsorption isotherm. It may be positive or negative values. The more positive value of $(a)$, the steeper is the adsorption isotherm.

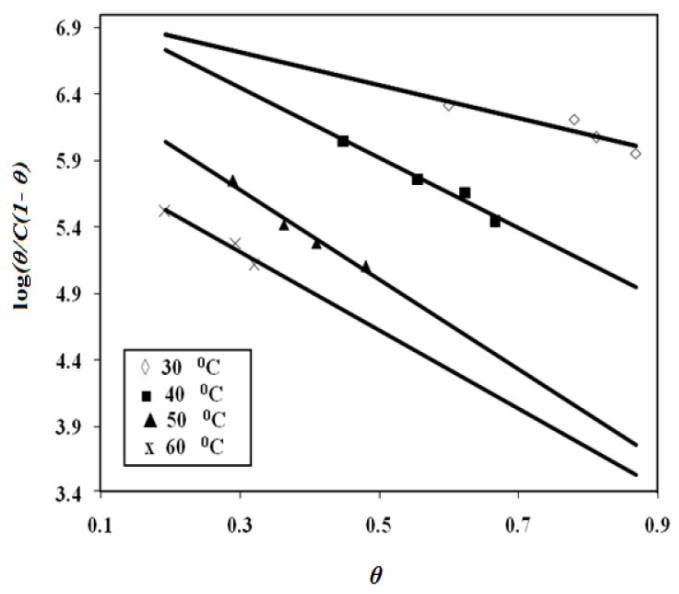

Figure 4. Frumkin adsorption isotherm of $\mathrm{PC}_{12} \mathrm{H}$ at different temperatures.

The apparent thermodynamic parameters $\left(\Delta H_{\mathrm{ads}}\right.$ and $\left.\Delta S_{\mathrm{ads}}\right)$ for the surfactant adsorption on the aluminum surface in $0.5 \mathrm{M} \mathrm{HCl}$ at different temperatures were determined from the slopes and intercepts of the lines of $\log K_{\mathrm{ads}}$ vs. $1 / T$ plots using the following equation [18,19]:

$$
\log K_{\text {ads }}=-\Delta H_{\text {ads }} / 2.303 R T+\Delta S_{\text {ads }} / 2.303 R
$$

where $\Delta H_{\text {ads }}$ and $\Delta S_{\text {ads }}$ are the enthalpy and entropy of the adsorption process, respectively. Values $\left(K_{\mathrm{ads}}\right),\left(\Delta H_{\mathrm{ads}}\right),\left(\Delta S_{\mathrm{ads}}\right)$ and $\left(\Delta \mathrm{G}_{\mathrm{ads}}\right)$ were obtained and listed in Table 3. The calculated values of $\Delta G_{\text {ads }}$ in case of $\mathrm{PC}_{12} \mathrm{H}\left(-41.6 \mathrm{~kJ} \mathrm{~mol}^{-1}\right)$ and in case of $\mathrm{PC}_{12} \mathrm{SO}_{3} \mathrm{H}\left(-36.45 \mathrm{~kJ} \mathrm{~mol}^{-1}[18]\right)$ are close to $-40 \mathrm{~kJ} \mathrm{~mol}^{-1}$; this reflects 
electrostatic interaction between the inhibitor and the charged metal surface and this adsorption process is described as physical adsorption [30]. These data are also in a good agreement with the data obtained from the thermodynamic activation parameters.

Table 3. Thermodynamic parameters of adsorption process based on Frumkin isotherm.

\begin{tabular}{|c|c|c|c|c|c|}
\hline $\mathbf{T}$ & $\boldsymbol{K}_{\text {ads }} \times \mathbf{1 0}^{-\mathbf{6}}$ & $\mathbf{- a}$ & $\begin{array}{c}\Delta \boldsymbol{H}_{\text {ads }} \\
\mathbf{K J} \mathbf{~ m o l}^{\mathbf{1}}\end{array}$ & $\begin{array}{c}\Delta \boldsymbol{S}_{\text {ads }} \\
\mathbf{k J ~ m o l}^{\mathbf{1}} \mathbf{K}^{-\mathbf{1}}\end{array}$ & $\begin{array}{c}\Delta \boldsymbol{G}_{\text {ads }} \\
\mathbf{k J} \mathbf{~ m o l}^{\mathbf{1}}\end{array}$ \\
\hline 303 & 1.21 & 0.62 & & & \\
313 & 1.01 & 1.32 & -49.02 & -0.025 & -41.6 \\
323 & 0.44 & 1.69 & & & \\
333 & 0.21 & 1.98 & & & \\
\hline
\end{tabular}

\section{Quantum Chemical Calculation}

\section{Molecular Reactivity}

The optimized geometries of $\mathrm{PC}_{12} \mathrm{H}$ and $\mathrm{PC}_{12} \mathrm{SO}_{3} \mathrm{H}$ are shown in Fig. 5 as well as bond lengths, bond angles and dihedral angles are tabulated in Table 4. Electronic behavior of $\mathrm{PC}_{12} \mathrm{H}$ and $\mathrm{PC}_{12} \mathrm{SO}_{3} \mathrm{H}$ was studied to explain the electron donor/acceptor properties of these compounds. The effectiveness of a particular donor/acceptor can be assessed by computation of certain quantum chemical parameters such as the energy of the highest occupied molecular orbital $\left(E_{\mathrm{HOMO}}\right)$, the energy of the lowest unoccupied molecular orbital $\left(E_{\text {LUMO }}\right)$ and LUMOHOMO gap ( $\left.E_{\mathrm{LUMO}}-E_{\mathrm{HOMO}}\right)$. $E_{\mathrm{HOMO}}$ is a quantum chemical descriptor, which is often associated with the electron donating ability of the molecule.

High value of $E_{\mathrm{HOMO}}$ indicates the tendency of a molecule to donate electrons to an appropriate acceptor molecule with empty molecular orbitals. Therefore, the energy of $E_{\text {LuMo }}$ indicates the ability of a molecule to accept electrons. On the other hand, values of energy gap $\left(\Delta E=E_{\mathrm{LUMO}}-E_{\mathrm{HOMO}}\right)$ are the measure of excitation energy to remove an electron from the last occupied molecular orbital. Hence, an increase in the values of $E_{\mathrm{HOMO}}$ can facilitate the disposition of the molecule to donate orbital electrons to an appropriate acceptor and decrease in $E_{\text {LUMO }}$ is an indication of strong interaction with the metal [27].

Figs. 6 and 7 represent the highest occupied molecular orbital (HOMO) and lowest occupied molecular orbital $(L U M O)$ for $\mathrm{PC}_{12} \mathrm{H}$ and $\mathrm{PC}_{12} \mathrm{SO}_{3} \mathrm{H}$, respectively. It could be seen that the frontier molecular orbitals of two compounds are generally located on the head group that be preferentially adsorbed onto the metal surface as active sites. It can be observed that HOMO energy of $\mathrm{PC}_{12} \mathrm{H}$ and $\mathrm{PC}_{12} \mathrm{SO}_{3} \mathrm{H}$ is -6.275 and $-6.278 \mathrm{eV}$, respectively. These results indicate that the electron donating behaviour of these compounds follows the order $\mathrm{PC}_{12} \mathrm{H}>\mathrm{PC}_{12} \mathrm{SO}_{3} \mathrm{H}$. On the other hand, the $L U M O$ energies of $\mathrm{PC}_{12} \mathrm{H}$ and $\mathrm{PC}_{12} \mathrm{SO}_{3} \mathrm{H}$ are -5.016 and $-4.864 \mathrm{eV}$, respectively, which indicates that the capability of accepting electrons of the studied compounds follows the order $\mathrm{PC}_{12} \mathrm{H}>\mathrm{PC}_{12} \mathrm{SO}_{3} \mathrm{H}$. 

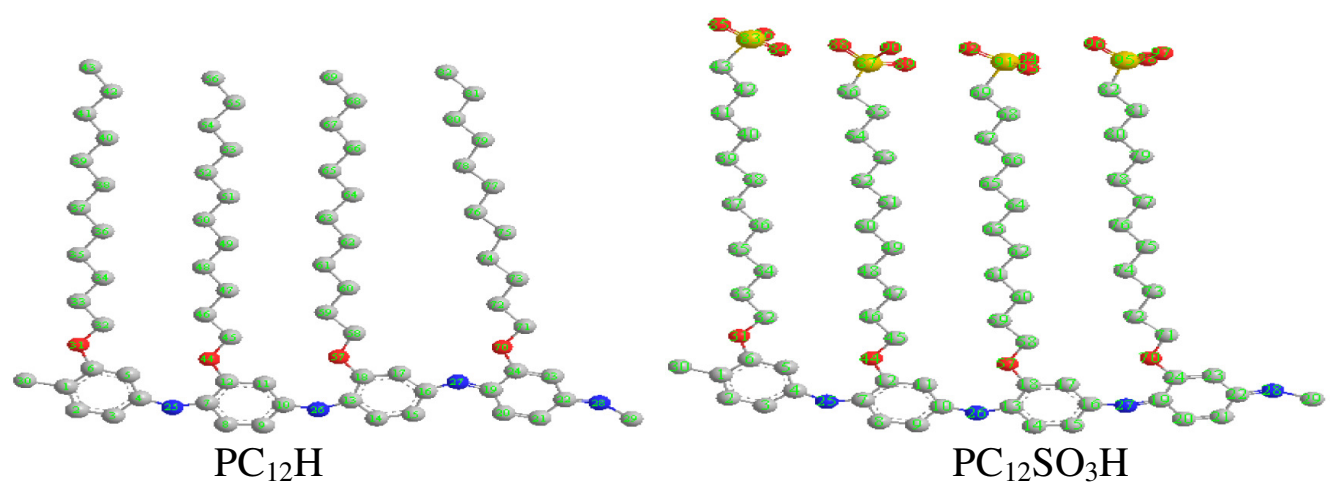

Figure 5. Optimized geometry of $\mathrm{PC}_{12} \mathrm{H}$ and $\mathrm{PC}_{12} \mathrm{SO}_{3} \mathrm{H}$.

Low value of energy gap $(\Delta E)$ leads to easier polarization of the molecule and greater adsorption on the surface. Thus, a small $\Delta E$ of $\mathrm{PC}_{12} \mathrm{H}(1.259 \mathrm{eV})$ facilitates its adsorption on aluminum metal and enhances its inhibition efficiency $(P \%=88.7)$ compared with $\mathrm{PC}_{12} \mathrm{SO}_{3} \mathrm{H}(P \%=55.1)$. This behaviour is in a good agreement with the results obtained from the polarization measurements.

Table 4. Bond length $\left(\mathrm{A}^{\mathrm{o}}\right)$, bond angle $\left({ }^{\circ}\right)$ and dihedral angle $\left(^{\circ}\right)$ for the optimized molecules at MM+.

\begin{tabular}{|c|c|c|c|c|c|}
\hline Geometry parameter & $\mathbf{P C}_{12} \mathrm{H}$ & $\mathrm{PC}_{12} \mathrm{SO}_{3} \mathrm{H}$ & Geometry parameter & $\mathbf{P C}_{12} \mathrm{H}$ & $\mathrm{PC}_{12} \mathrm{SO}_{3} \mathrm{H}$ \\
\hline \multicolumn{3}{|c|}{ Bond length } & \multicolumn{3}{|c|}{ Bond angle } \\
\hline $\mathrm{C}(1)-\mathrm{C}(30)$ & 1.515 & 1.515 & $\mathrm{O}(31)-\mathrm{C}(6)-\mathrm{C}(1)$ & 116.4 & 115.9 \\
\hline$C(1)-C(6)$ & 1.350 & 1.351 & $C(1)-C(6)-C(5)$ & 118.1 & 118.1 \\
\hline$C(1)-C(2)$ & 1.340 & 1.350 & $\mathrm{C}(1)-\mathrm{C}(2)-\mathrm{C}(3)$ & 120.4 & 120.0 \\
\hline $\mathrm{C}(4)-\mathrm{N}(25)$ & 1.276 & 1.278 & $\mathrm{C}(4)-\mathrm{N}(25)-\mathrm{C}(7)$ & 146.6 & 146.6 \\
\hline $\mathrm{N}(25)-\mathrm{C}(7)$ & 1.279 & 1.279 & $\mathrm{~N}(25)-\mathrm{C}(7)-\mathrm{C}(12)$ & 132.8 & 132.1 \\
\hline $\mathrm{C}(16)-\mathrm{N}(27)$ & 1.268 & 1.260 & $\mathrm{~N}(25)-\mathrm{C}(7)-\mathrm{C}(8)$ & 109.6 & 110.6 \\
\hline $\mathrm{C}(19)-\mathrm{N}(27)$ & 1.269 & 1.261 & $\mathrm{~N}(25)-\mathrm{C}(4)-\mathrm{C}(5)$ & 131.1 & 131.9 \\
\hline $\mathrm{C}(22)-\mathrm{N}(28)$ & 1.261 & 1.261 & $\mathrm{C}(32)-0(31)-\mathrm{C}(6)$ & 120.6 & 122.2 \\
\hline $\mathrm{O}(70)-\mathrm{C}(24)$ & 1.379 & 1.378 & $\mathrm{C}(12)-\mathrm{O}(44)-\mathrm{C}(45)$ & 120.1 & 119.9 \\
\hline $\mathrm{O}(57)-\mathrm{C}(18)$ & 1.380 & 1.380 & $\mathrm{C}(58)-\mathrm{O}(57)-\mathrm{C}(18)$ & 101.7 & 118.8 \\
\hline $\mathrm{O}(44)-\mathrm{C}(12)$ & 1.370 & 1.370 & $\mathrm{C}(24)-\mathrm{O}(70)-\mathrm{C}(71)$ & 122.8 & 118.5 \\
\hline $\mathrm{O}(31)-\mathrm{C}(6)$ & 1.373 & 1.373 & $\mathrm{C}(23)-\mathrm{C}(22)-\mathrm{C}(21)$ & 117.9 & 118.1 \\
\hline \multicolumn{3}{|c|}{ Dihedral angle } & $\mathrm{C}(22)-\mathrm{N}(28)-\mathrm{C}(23)$ & 117.6 & 117.7 \\
\hline $\mathrm{C}(1)-\mathrm{C}(2)-\mathrm{C}(3)-\mathrm{C}(4)$ & -0.011 & 0.528 & $\mathrm{C}(12)-\mathrm{C}(7)-\mathrm{C}(8)$ & 117.6 & 122.4 \\
\hline $\mathrm{C}(4)-\mathrm{N}(25)-\mathrm{C}(7)-\mathrm{C}(8)$ & 179.9 & 177.3 & $\mathrm{C}(11)-\mathrm{C}(10)-\mathrm{C}(9)$ & 114.8 & 115.2 \\
\hline $\mathrm{C}(11)-\mathrm{C}(12)-\mathrm{C}(7)-\mathrm{N}(25)$ & 180 & 179.3 & $\mathrm{C}(18)-\mathrm{C}(13)-\mathrm{C}(14)$ & 117.6 & 118.4 \\
\hline $\mathrm{C}(8)-\mathrm{C}(9)-\mathrm{C}(10)-\mathrm{C}(11)$ & 180 & 0.161 & $\mathrm{C}(10)-\mathrm{N}(26)-\mathrm{C}(13)$ & 145.9 & 146.8 \\
\hline $\mathrm{C}(24)-\mathrm{C}(19)-\mathrm{N}(27)-\mathrm{C}(16)$ & 180 & 0.376 & $\mathrm{C}(19)-\mathrm{N}(27)-\mathrm{C}(16)$ & 137.6 & 161.9 \\
\hline $\mathrm{O}(1)-\mathrm{C}(24)-\mathrm{C}(19)-\mathrm{C}(20)$ & 180 & -178.9 & & & \\
\hline
\end{tabular}

Electrostatic potential surface

Electrostatic potential surface generally provides information regarding the chemical reactivity of a molecule. The electrostatic potential generated in the space around a molecule by the charge distribution is helpful to understand how much electrophilic or nucleophilic the molecular species is.

Fig. 8 represents the electrostatic potential map for $\mathrm{PC}_{12} \mathrm{H}$ and $\mathrm{PC}_{12} \mathrm{SO}_{3} \mathrm{H}$. Results show that $\mathrm{PC}_{12} \mathrm{SO}_{3} \mathrm{H}$ has a more negative charge than $\mathrm{PC}_{12} \mathrm{H}$, therefore, the electrophilicity of $\mathrm{PC}_{12} \mathrm{H}$ is higher than that of $\mathrm{PC}_{12} \mathrm{SO}_{3} \mathrm{H}$. These results explain the good electrostatic attraction between $\mathrm{PC}_{12} \mathrm{H}$ and the negatively 
charged aluminum surface and thus, the higher adsorption and inhibition efficiency for $\mathrm{PC}_{12} \mathrm{H}$ compared with that of $\mathrm{PC}_{12} \mathrm{SO}_{3} \mathrm{H}$. These theoretical calculations are in a good agreement with the experimental results.

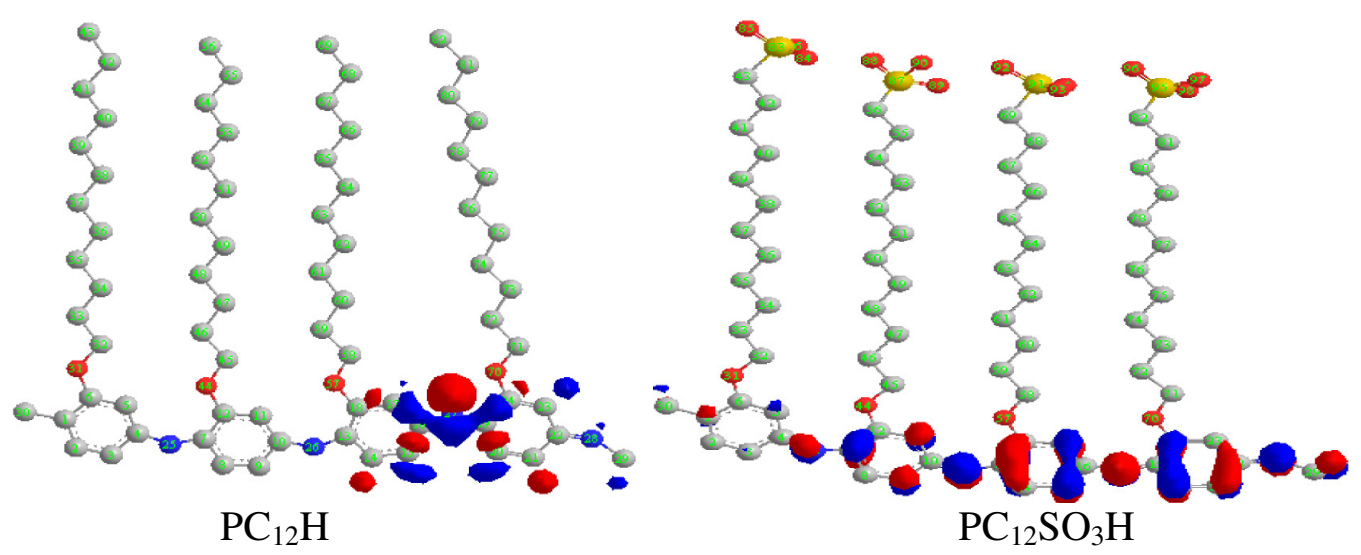

Figure 6. $\mathrm{HOMO}$ distribution of $\mathrm{PC}_{12} \mathrm{H}$ and $\mathrm{PC}_{12} \mathrm{SO}_{3} \mathrm{H}$.

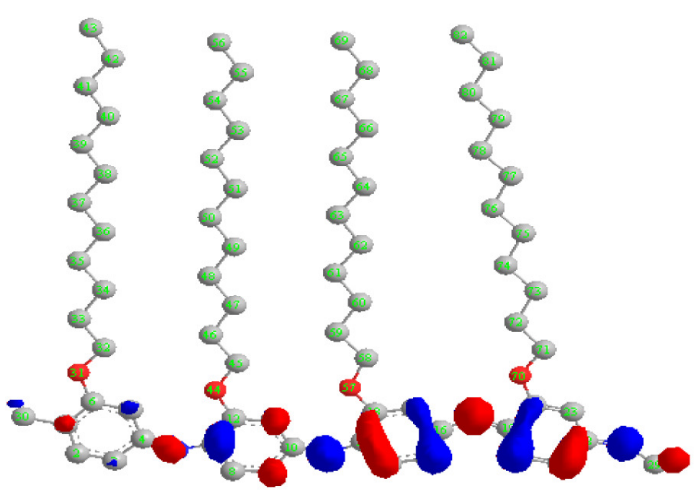

$\mathrm{PC}_{12} \mathrm{H}$

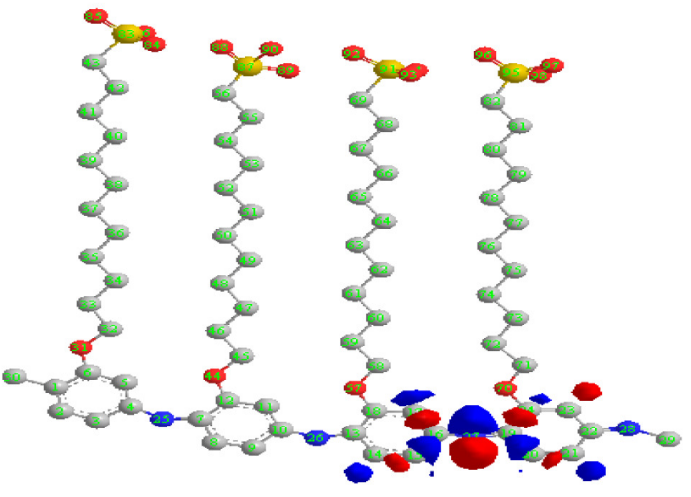

$\mathrm{PC}_{12} \mathrm{SO}_{3} \mathrm{H}$

Figure 7. LUMO distribution of $\mathrm{PC}_{12} \mathrm{H}$ and $\mathrm{PC}_{12} \mathrm{SO}_{3} \mathrm{H}$.

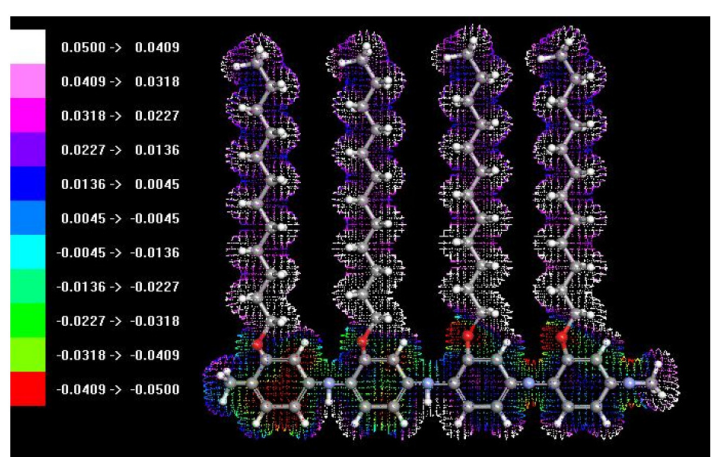

$\mathrm{PC}_{12} \mathrm{H}$

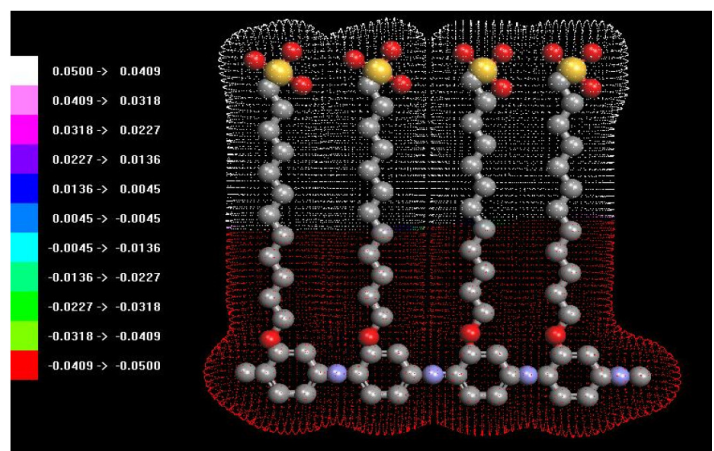

$\mathrm{PC}_{12} \mathrm{SO}_{3} \mathrm{H}$

Figure 8. Surface electrostatic potential of $\mathrm{PC}_{12} \mathrm{H}$ and $\mathrm{PC}_{12} \mathrm{SO}_{3} \mathrm{H}$. 


\section{Conclusions}

- The terminal side chain has a great effect on the inhibition efficiency of the studied polymeric surfactants.

- Inhibition efficiency of $\mathrm{PC}_{12} \mathrm{H}$ is higher than that of $\mathrm{PC}_{12} \mathrm{SO}_{3} \mathrm{H}$.

- Inhibition efficiency increases with increasing the inhibitor concentrations but decreases with raising the temperature.

- Physical adsorption was suggested for both polymeric surfactant inhibitors.

- Langmuir and Frumkin isotherms are found to fit the adsorption of the studied compounds.

-Quantum chemical calculations and the electrostatic potential surface explain the effect of the terminal side chain on the inhibition efficiency for both studied polymeric surfactant compounds.

\section{References}

1. Sorkhabi HA, Ghasemi Z, Seifzadeh D. Appl Surf Sci. 2005;247:408-418.

2. Maayta AK, AL-Rawashdeh NA. Corros Sci. 2004;46:1129-1140.

3. Branzoi V, Golgovici F, Branzoi F. Mater Chem Phys. 2002;78:122-131.

4. Sherif EM, Park SM. Electrochim Acta 2006;51:1313-1321.

5. Abd El Rehim SS, Hassan H, Amin M. Mater Chem Phys. 2002;78:337348.

6. Zhao T, Mu G.. Corros Sci. 1999;41:1937-1944.

7. Perucki M, Chandrasekhar P. Synth Met. 2001;119:385-386.

8. Breslin C, Fenelon A, Conroy K. Mater Des. 2005;26:233-237.

9. Gelling VJ, Wiest MM, Tallman DE, et al. Prog Org Coat. 2001;43:149157.

10. Epstein AJ, Smallfield JA, Guan H, et al. Synth Met. 1999;102:1374-1376.

11. Muller B. Corros Sci. 2004;46:159-167.

12. Bereket G, Yurt A. Corros Sci. 2001;43:1179-1195.

13. Foad El-Shebini EE, Abd-El-Wahab SM, Deyab MA. Mater Chem Phys. 2003;82:631-637.

14. Maitra A, Barua S. Corros Sci. 1974;14:587-590.

15. Moussa MN, Taha FI, Gouda MA, et al. Corros Sci. 1976;16:379-385.

16. Zheludkevich ML, Yasakau KA, Poznyak S, et al. Corros Sci. 2004;47:3368-3383.

17. Sayyah SM, Abd El-Rehim SS, El-Deeb MM, et al. Egypt J Chem. 2012;55:583-602.

18. El-Deeb MM, Sayyah SM, Abd El-Rehim SS, et al. Arab J Chem. In press. http://dx.doi.org/10.1016/j.arabjc.2013.09.018.

19. El-Deeb MM, Mohamed SM. J Appl Polym Sci. 2011;122:3030-3037.

20. Camacho RL, Montiel E, Jayanthi N, et al. Chem Phys Lett. 2010;485:142151.

21. Musa AY, Mohamed A, Kadhum AH, et al. J Ind Eng Chem. 2012;18:551555.

22. Danaee I, Ghasemi O, Rashed GR, et al. J Mol Struct. 2013;1035:247-259. 
23. Zhang J, Qiao G, Hu S, et al. Corros Sci. 2011;53:147-152.

24. Sayyah SM, El-Salam HMA, Azzam EM. Inter J Polym Mat. 2006;55:1075-1093.

25. Saliyana VR, Adhikari AV.Corros Sci. 2008;50:55-61.

26. Musa AY, Jalgham RT, Mohamed A.Corros Sci. 2012;56:176-183.

27. Obot IB, Obi-Egbedi NO. Curr Appl Phys. 2011;11:382-392.

28. Saleh MM, Atia AA.J Appl Electrochem. 2006; 36:899-905.

29. Obot IB, Obi-Egbedi NO. Corros Sci. 2010;52:198-204.

30. Abd-El-Rehim SS, Sayyah SM, El-Deeb MM, et al. Mater Chem Phys. 2010;123:20-27. 